\title{
EXPERIMENTAL TESTS OF PARAMETERS CHARACTERIZING THE COOPERATION OF POWERED ROOF SUPPORT BASE AND FLOOR OF LOW BEARING CAPACITY
}

\section{DOBÓR PARAMETRÓW CHARAKTERYZUJĄCYCH POSTAĆ KONSTRUKCYJNĄ SEKCJI OBUDOWY ZMECHANIZOWANEJ W ASPEKCIE JEJ WSPÓŁPRACY ZE SPĄGIEM O MALEJ NOŚNOŚCI}

Results of experimental tests aiming at determination of base pressure on the floor, carried out within "Geosoft" project, are presented. The tests included stand tests carried out with use of unique measuring instrumentation and special hydraulic cushion as well as tests of load of roof support set to load in operating longwall panel. The measurement results confirmed the necessity to consider the 3D model of cooperation of base and floor. Factors having impact on distribution of base pressure on the floor and its maximal value were identified, taking into account the test results.

Keywords: powered roof support, pressure on the floor, measurements

W artykule przedstawiono zagadnienie eksperymentalnego wyznaczania parametrów charakteryzujących współpracę spagnicy sekcji obudowy zmechanizowanej ze spąiem o małej nośności. Doświadczalna analiza współpracy spągnicy typu katamaran ze spagiem była przedmiotem badań zrealizowanych w ramach międzynarodowego projektu badawczego pt.: "Geomechanika słabych spągów i ociosów" o akronimie GEOSOFT (Geosoft, 2013) współfinansowanego przez Fundusz Badawczy dla Węgla i Stali. Przeprowadzono badania laboratoryjne z wykorzystaniem specjalnie do tego celu skonstruowanej i oprzyrządowanej sekcji obudowy zmechanizowanej typu BW 16/34 POz. Oprzyrządowanie sekcji stanowił układ pomiarowy umożliwiający monitorowanie, wizualizację, a także archiwizację ciśnienia w stojakach sekcji i w siłowniku podpory stropnicy (Rys. 3), cech geometrycznych sekcji (Rys. 4) oraz odkształceń w wybranych punktach elementów sekcji (Rys. 5). Badania laboratoryjne sekcji obudowy BW 16/34 POz przeprowadzono na stanowisku badawczym umożliwiającym obciążanie sekcji poprzez aktywny ruch stropu. Celem modelowania nośności spągu sekcję posadowiono na „,poduszce hydraulicznej” (Rys. 7) zbudowanej z 24 siłowników o indywidualnie regulowanych nastawach. Wysokość sekcji rozpartej w stanowisku mieściła się w zakresie wysokości stosowania sekcji w ścianach, w których zaplanowano pomiary dołowe. Stwierdzono, że nawet w przypadku symetrycznego podparcia stropnicy (Rys. 8) obciążenie spagnicy jest niesymetryczne. Zarejestrowany niesymetryczny rozkład nacisku spagnicy na spag nie został spowodowany ani niesymetrycznym obciążeniem stropnicy, ani nierównomiernym rozkładem nastaw bloków zaworowych w siłownikach poduszki hydraulicznej.

* INSTITUTE OF MINING MECHANISATION, FACULTY OF MINING AND GEOLOGY, SILESIAN UNIVERSITY OF TECHNOLOGY, AKADEMICKA 2, 44-100 GLIWICE, POLAND

** CENTRAL MINING INSTITUTE, PLAC GWARKÓW 1, 40-166 KATOWICE, POLAND 
Lokalizację miejsca badań dołowych przedstawiono na Rys. 9. Na rysunku 10 przedstawiono wykresy zmian ciśnienia w stojaku lewym i prawym sekcji zarejestrowane podczas biegu ściany. Stwierdzono, że chwilowe obciążenie sekcji jest niesymetryczne, a wartości ciśnienia w stojakach podczas poszczególnych cykli różnią się istotnie. Należy zaznaczyć, że podczas normalnego biegu ściany nie zauważono przejawów niszczenia struktury skał spagowych. Analizując procentowy rozkład obszaru kontaktu spagnicy ze spagiem wyznaczony na podstawie pomiarów w wyrobisku (Rys. 11) stwierdzono, że w przypadku niezawodnionego spagu o małej nośności współpraca spąnicy ze spagiem w tych warunkach jest korzystna, zarówno w aspekcie podporności sekcji, jak również wytężenia podstawowych jej elementów.

Wyniki pomiarów, wykonanych w wyrobisku ścianowym, jak również na stanowisku badawczym uzasadniają konieczność modelowania współpracy spagnicy ze spąiem z wykorzystaniem modeli przestrzennych. Przeprowadzone badania stanowiskowe i dołowe umożliwiły zidentyfikowanie czynników istotnie wpływających na współpracę spagnicy ze spąiem.

Słowa kluczowe: sekcja obudowy zmechanizowanej, nacisk na spąg, modelowanie, pomiary

\section{Introduction}

In the case of longwall mining in conditions of low bearing capacity of floor rocks the distribution of pressure of powered roof support base on the floor is of significant importance. Low bearing capacity of the floor in combination with uneven distribution of pressure results in significant deterioration of conditions for supporting the roof and in difficult advance of roof support following the longwall face. Due to this, the problem of determination of distribution of pressure on the floor was the subject of many research projects, including experimental ones (Fokin et al., 1980; Aleksandrov, 1971). The laboratory tests consisted in measurements of pushing the base to the plastic ground (Peng \& Chiang, 1984; Wala, 1976) or measurements of pressure to the floor with use of special measuring mat, which consists of force sensors installed in conveyor belt (Gricajuk, 1979). Measuring mats were also used for taking the measurements in a longwall panel (Fokin et al., 1980). Distribution of base pressure on the floor in the plane perpendicular to the longwall face was determined basing on the measurement results. Due to the use of separate bases of beam type, the distribution of pressure in the plane parallel to the longwall face was not determined, and it was assumed that it was an even distribution. Use of the bases of catamaran type in powered roof supports, manufactured at present, caused that the importance of distribution of base pressure on the floor in the plane parallel to the longwall face increased.

This problem was, among others, the subject of tests carried out within international research project entitled "Geomechanics of soft floors and sides" of acronym GEOSOFT (Geosoft, 2013). This project, co-financed by the Research Fund for Coal and Steel (RFCR-CT-2010-00001), was realized in the years $2010 \div 2013$ in co-participation of, among others, Central Mining Institute (including representatives of the Faculty of Mining and Geology of the Silesian University of Technology), PKW ZG Janina and Becker Warkop.

\section{Experimental determination of distribution of pressure on the contact surface between catamaran base and floor}

Cooperation of powered roof support and floor rocks of low bearing capacity was analyzed within the GEOSOFT project. Both laboratory tests on a test stand at KOMAG and underground tests in ZG Janina were carried out with use of BW 16/34 POz powered roof support specially 
designed and equipped for that purpose. Legs of internal diameter $275 \mathrm{~mm}$, operating at starting pressure $25 \div 28 \mathrm{MPa}(1.48 \div 1.66 \mathrm{MN})$ and at operational pressure $45 \mathrm{MPa}(2.44 \mathrm{MN})$, were used in the roof support. The roof support was equipped with the measuring system enabling monitoring (with sampling frequency $1 \mathrm{~Hz}$ ), visualization, and archiving the following roof support parameters:

- pressure in under-piston area of both the legs of roof support and canopy cylinder (Fig. 1),

- geometrical features of powered roof support determined in the result of using the five inclinometers installed on the following components: canopy, shield, lemniscate links, base and legs (Fig. 2),

- deformation in eleven selected points of different components of roof support, determined with use of electro-resistant strain gauges (Fig. 3).
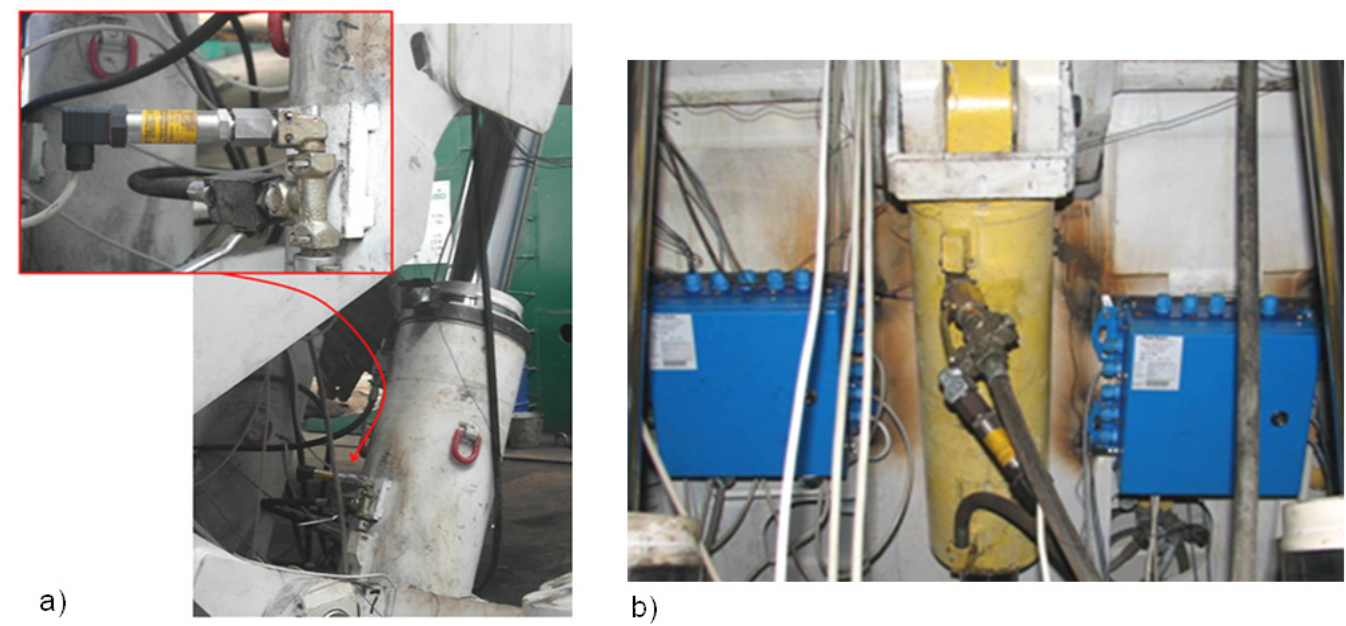

b)

Fig. 1. Pressure sensors installed in BW 16/34 POz roof supports

a) in the hydraulic leg, b) in the canopy cylinder

The components of measuring system presented above were used both in stand tests and measurements in the longwall panel.

\section{Stand tests}

Laboratory tests of BW 16/34 POz roof support were carried out at test rig at the KOMAG Institute of Mining Technology in Gliwice (Fig. 4). The rig enables loading the roof support through active movement of the roof, as it occurs in the longwall panel. To model the floor different bearing capacity during tests, the roof support set to load was founded in the rig on a "hydraulic cushion" (Fig. 5) built of 24 cylinders of individually controlled settings. The tests were carried out both for symmetrical and asymmetrical canopy load conditions (Fig. 6). The height of roof support set to load in the rig was $2.5 \mathrm{~m}$ and $3.3 \mathrm{~m}$, what corresponds to the height of roof support in longwalls in PKW S.A. ZG "Janina". 
a)
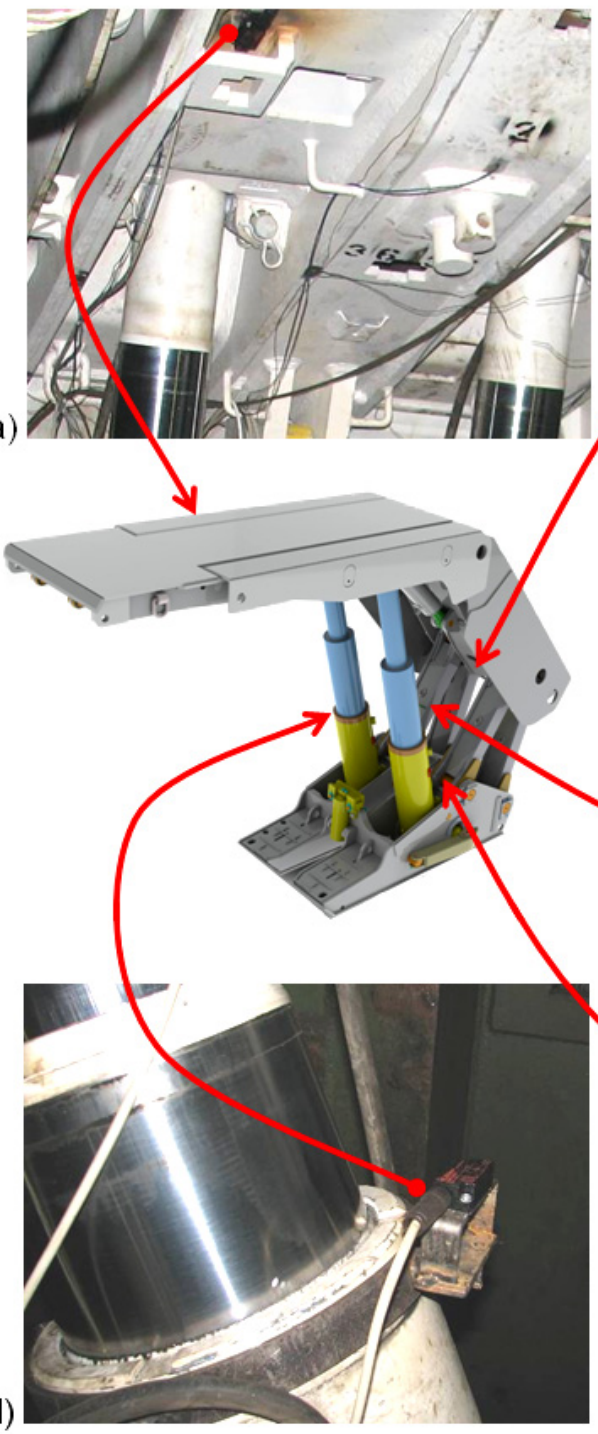

b)

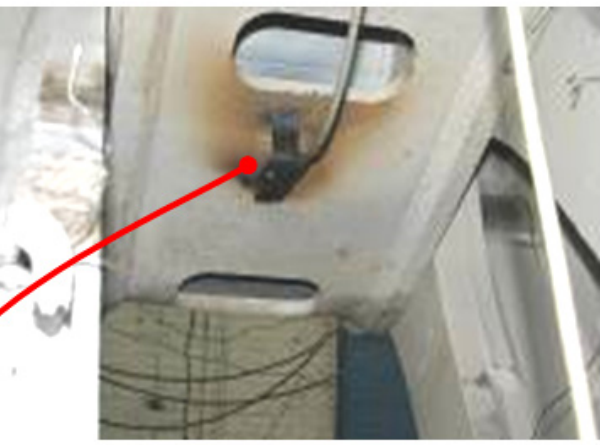

c)

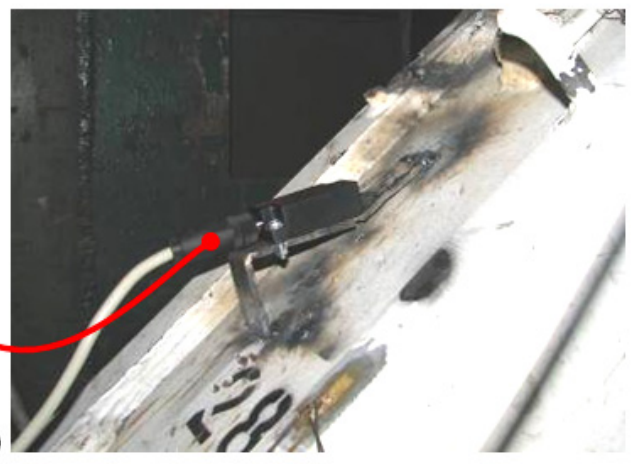

e)

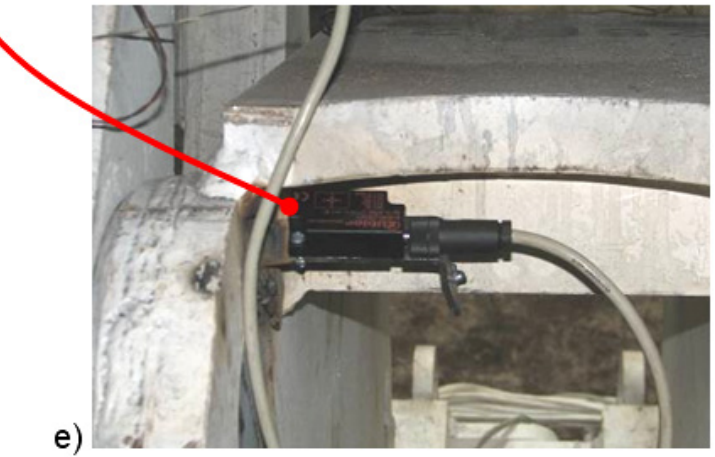

Fig. 2. Distribution of inclinometers on powered roof support

a) on the canopy, b) on the gob shield, c) on the lemniscate link, d) on the hydraulic leg,

e) on the base 


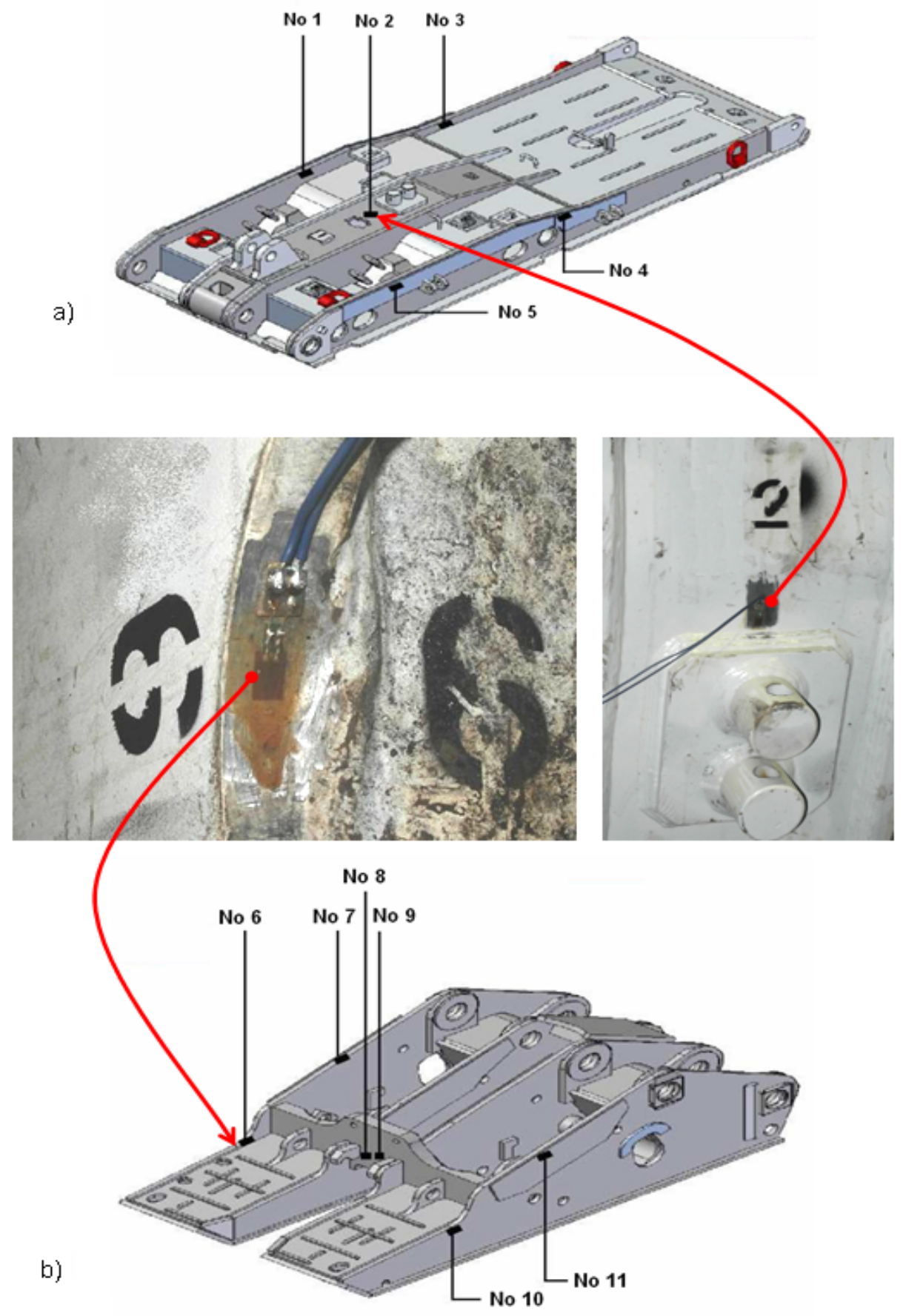

Fig. 3. Localization of strain gauges on powered roof support a) on the canopy, b) on the base 


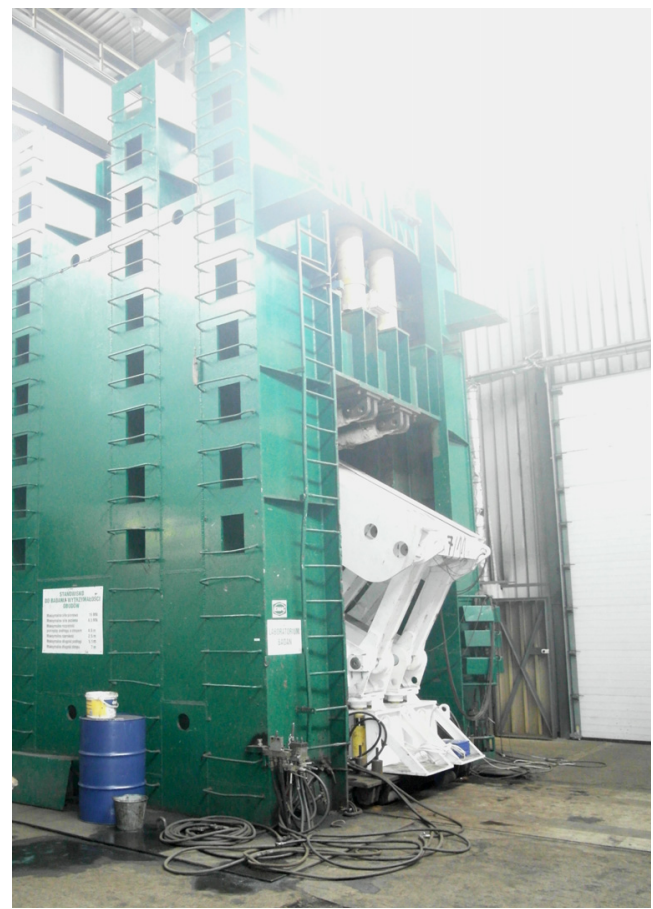

Fig. 4. BW 16/34 POz roof support placed in the test rig and founded on the "hydraulic cushion" at the KOMAG Institute of Mining Technology in Gliwice

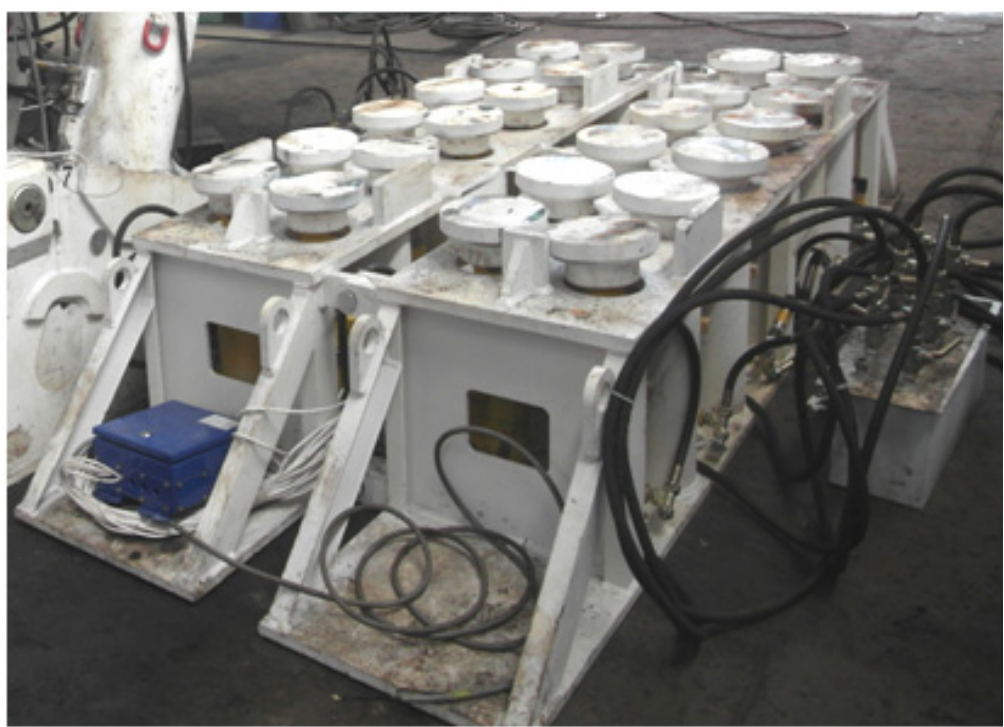

Fig. 5. Hydraulic cushion used during laboratory tests to simulate different values of compression strength of floor rocks and different arrangement of support scheme 


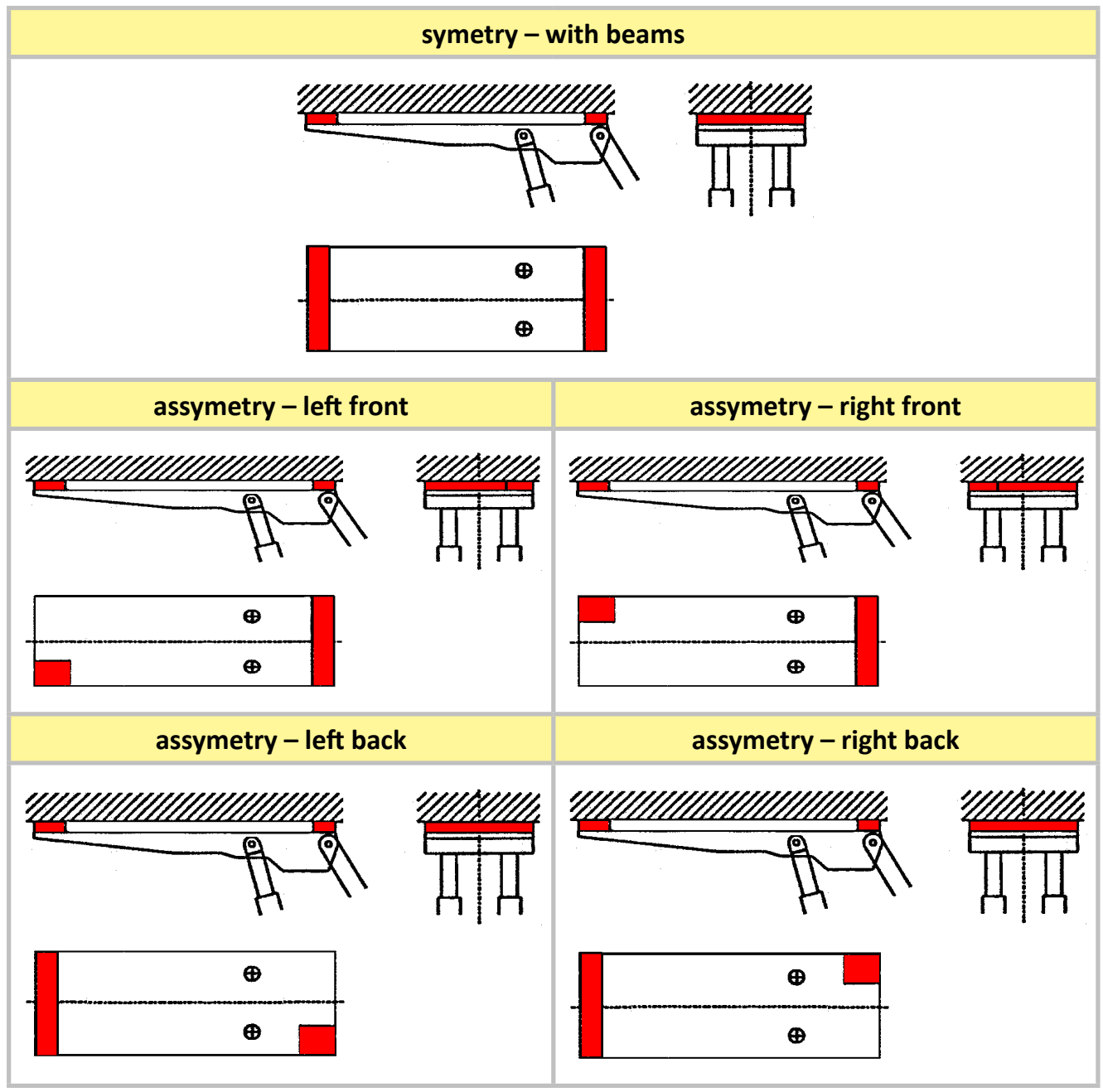

Fig. 6. Examples of load diagrams of powered roof support in the test rig

When analyzing the results of measurements of deformations in the selected points of roof support (Fig. 7) it was found that even at symmetrical loading of the canopy, confirmed by the readings of strain gauges 1-5 placed on the canopy, load to the base is asymmetrical, what results from comparison of strain gauges readings, e.g. No. 6 and 11 stuck to a side metal sheets of the base.

Recorded distribution of pressure in each cylinder of hydraulic cushion at symmetrical load to the canopy is presented in Fig. 8.

Recorded distribution of pressure indicates asymmetrical distribution of base pressure on the floor, which neither was caused by asymmetrical load to the canopy, nor by differentiated settings of valve blocks in the cylinders of hydraulic cushion. Uneven distribution of load to kinematic nods of roof support, caused by assembly clearances and manufacture inaccuracy of these nods, is the most probable reason of asymmetrical pressure distribution. 


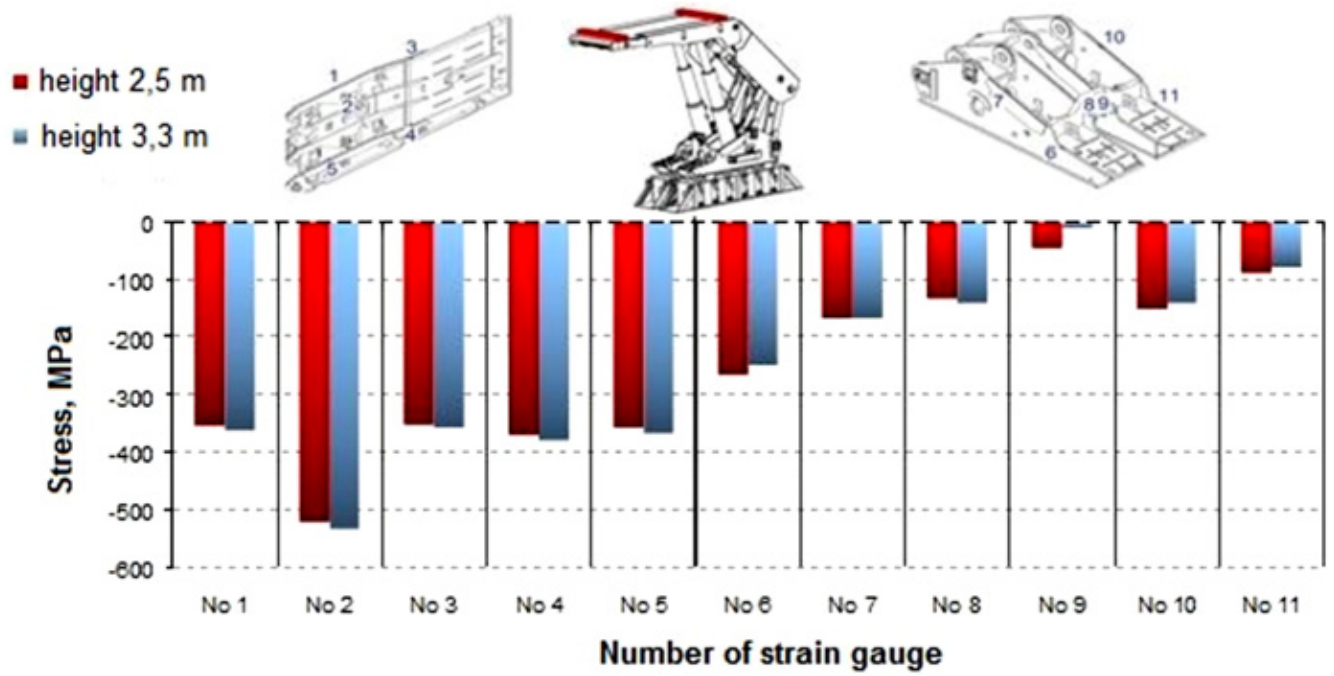

Fig. 7. Comparison of strain in each powered roof support point determined on the basis of tensometric measurements at symmetrical load

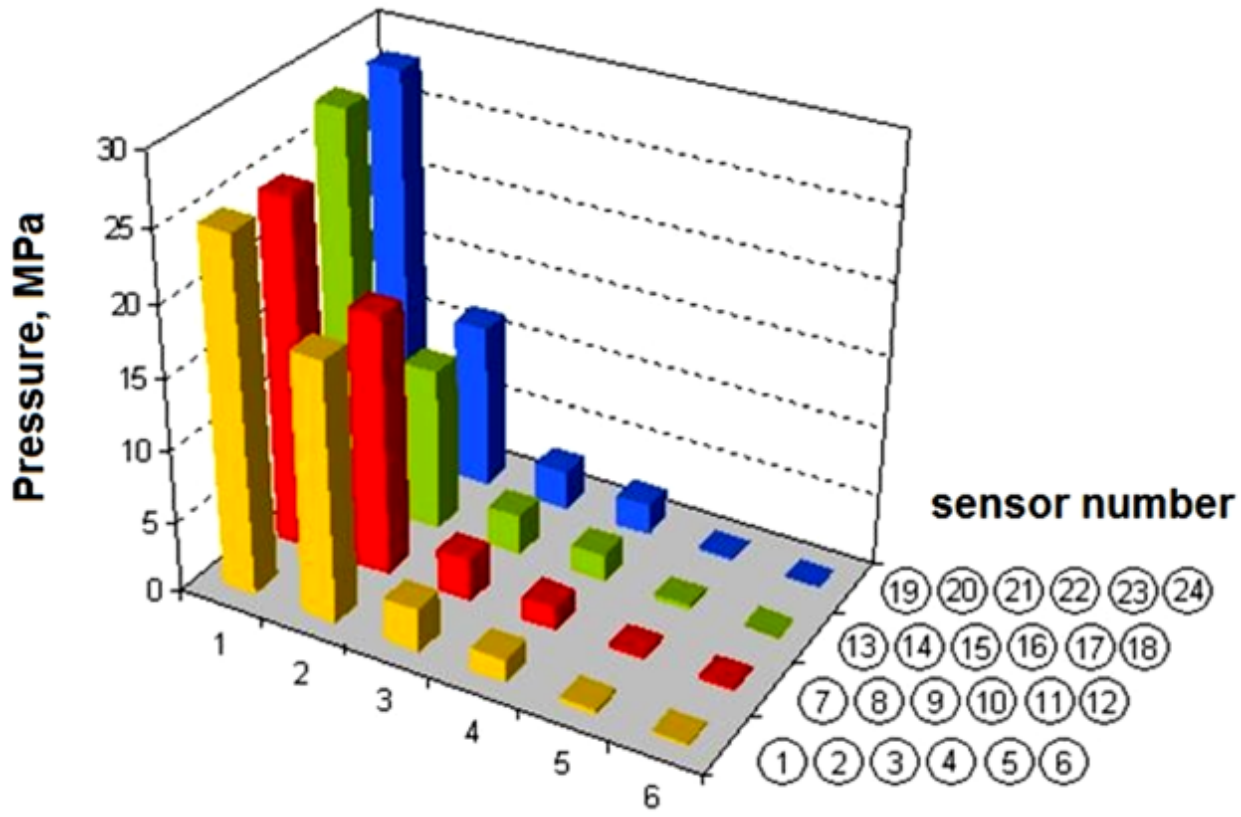

Fig. 8. Distribution of pressure in the cylinders of hydraulic cushion at symmetrical load to canopy during laboratory tests 


\section{Testing the load to powered roof support used in ZG Janina in conditions of soft floor rocks}

The first underground tests of BW 16/34 POz roof support equipped with the described system for load monitoring were carried out in ZG "Janina" in longwall No. 136 in the NorthEast part of "Libiąż IV" Mining Area, in the seam 119/2, part B1. Localization of place of testing (section 119) is presented in Fig. 9.

Seam 119/2 in the area of planned longwall No. 136 is deposited at the depth $360 \div 430 \mathrm{~m}$ and consists of coal layers of thickness: $0.20-0.36 \mathrm{~m}, 0.20-0.45 \mathrm{~m}, 0.80-1.00 \mathrm{~m}, 0.30-0.40 \mathrm{~m}$ and 0.9-1.30 m. These layers are separated by the shale of thickness varying from 0.03 to $0.25 \mathrm{~m}$. In the seam roof there is a shale layer of thickness of up to $2.1 \mathrm{~m}$, and above $5.6 \mathrm{~m}$ of sandstone. The floor is a layer of mudstone or shale of thickness of up to $1.8 \mathrm{~m}$.

Strength $R_{c}$ of coal in seam $119 / 2$ and the surrounding rocks, which have a tendency to soaking and expansion, determined on the basis of penetrometric tests was: $7.7 \div 10.3 \mathrm{MPa}$ for the roof, 13.2 MPa for the floor and 6.5 MPa for coal in the seam.

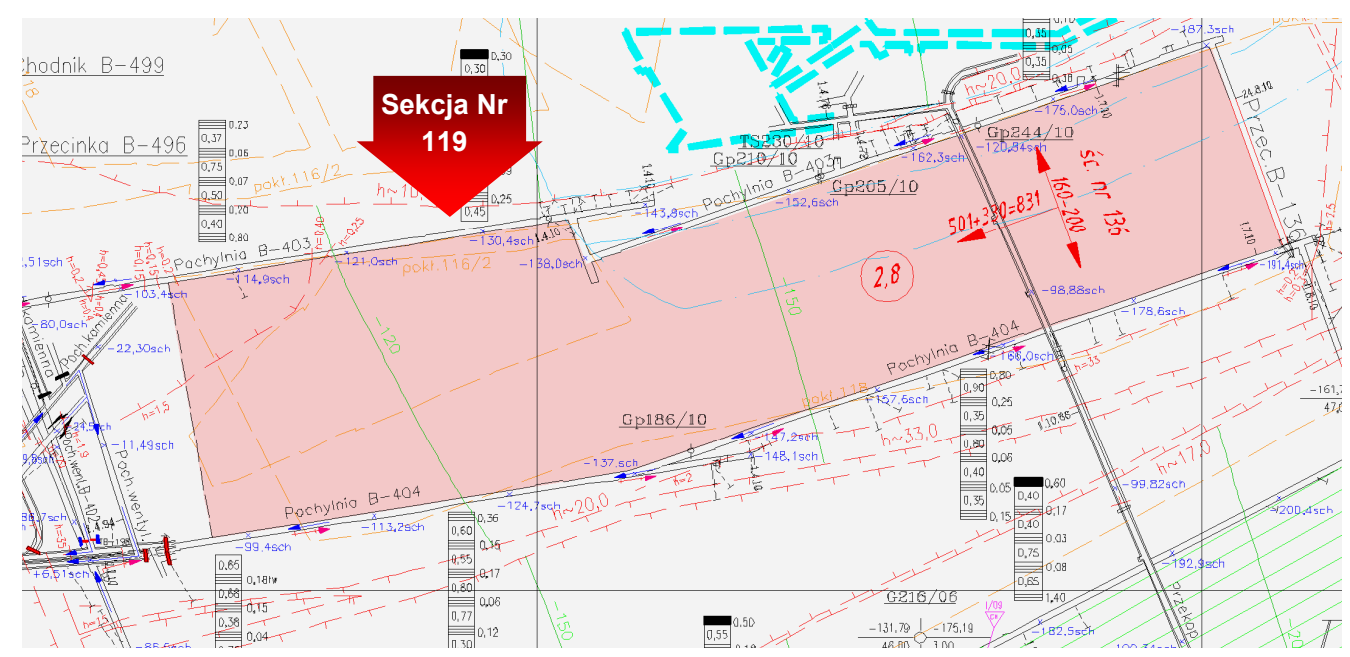

Fig. 9. Location of BW 16/34 POz (No.119) roof support in longwall 136 - seam 119/2

Diagrams of pressure changes in the left and right leg of the roof support, which were recorded along the longwall panel, are given in Fig. 10.

From the presented diagram it results that momentary load to the roof support is asymmetrical. Value of load is significantly different in each cycle of roof support operation. It should be mentioned that during normal longwall panel operation, in conditions of lack of water inflow to the working, the structure of floor rocks was not damaged by the base, what would result in "pressing and sinking" of roof support in the floor of the working. The ground reaction enabled to reach the operational load bearing capacity of roof support. 


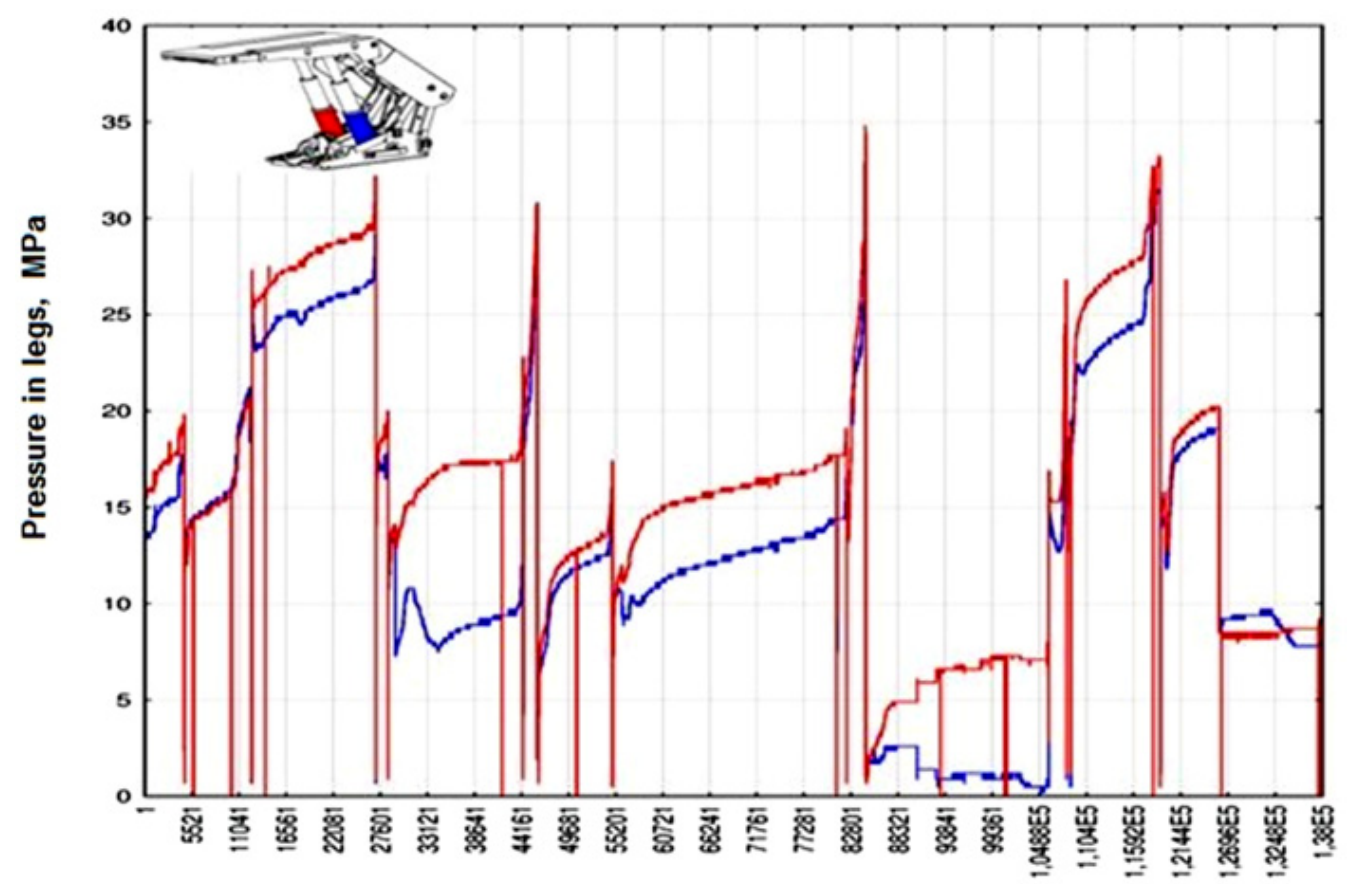

Sampling

Fig. 10. Examples of pressure recorded in under-piston parts of legs of BW 16/34 POz powered roof supports operating in the longwall No. 136 - seam 119/2

Use of inclinometers enabled precise determination of geometrical form of kinematic chain of roof support set to load in longwall 136 and including this form in analysis of distribution of permanent loading on the base surface. In Fig. 11, percentage share of contact area between base and floor determined by measurements taken in the working is presented. From the diagram in Fig. 11 it results that e.g. in the $37 \%$ cases the base has full contact with the floor. The lowest recorded contact area between floor and base was $60 \%$ (about $1 \%$ of recorded cases).

From the tests it results that in the case of not watered floor of low bearing capacity the changes of geometrical form of kinematic chain of roof support cause that contact surface of the base and roof covers over $60 \%$ of the surface of lower metal sheet of the base.

Thus, it can be said that cooperation between base and floor in these conditions is favourable, both in the aspect of roof support's load bearing capacity and effort of basic components of the roof support (Geosoft, 2013).

On the basis of measurements taken in longwall 136 and results of stand tests at KOMAG (Geosoft, 2013) it was proved that in the case of floor of high load bearing capacity (e.g. sand shale) cooperation of the same roof support with floor would be less favourable. 


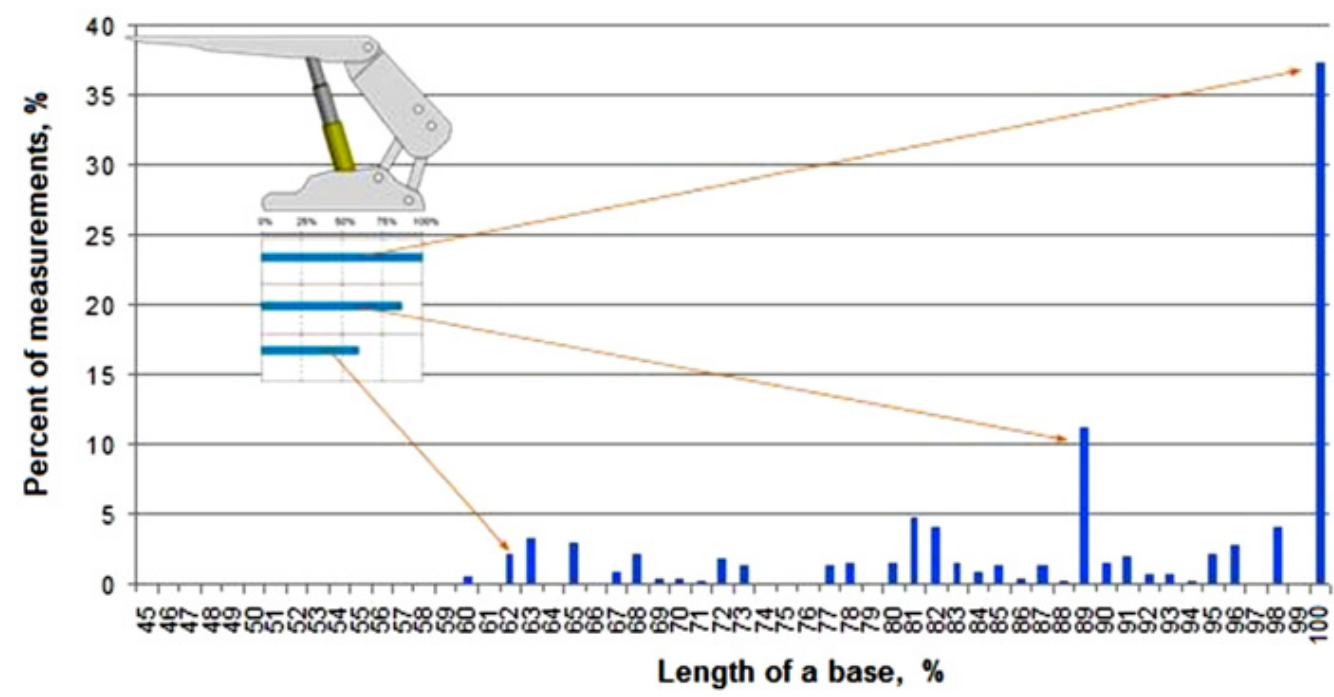

Fig. 11. Contact area between base and floor

\section{Summary}

Use of unique measuring instrumentation developed within Geosoft project enabled to determine distribution of catamaran base pressure on the floor. The scope of testing was significantly broader than the scope of previously carried out tests and it enabled to determine pressure changes on the entire contact surface of base and floor.

Analysis of determined distribution of pressure in planes parallel and perpendicular to the longwall face justified the need of such detailed tests as it was found that there are significant differences in distribution of pressure in planes parallel to the longwall face.

The results of stand tests showed that symmetrical load to the canopy causes uneven distribution of pressure in planes parallel and perpendicular to the plane of symmetry of roof support. Thus, uneven distribution of pressure is caused by design features - uneven distribution of rigidity and different values of friction forces in pairs of rotatable roof supports.

To summarize the results of stand tests it should be emphasized that reasons of uneven pressure distribution consist not only in uneven distribution of floor properties, but also in design features of the roof support.

In the case of not watered floor of small bearing capacity the changes of geometrical form of kinematic chain of roof support cause that contact surface of base and floor covers over $60 \%$ of the surface of lower metal sheet of the base. Cooperation of base and floor in such conditions is favourable, both in the aspect of load bearing capacity of roof support and effort of its basic components. It was also proved that in the case of floor of high bearing capacity the cooperation of the same roof support with floor would be less favourable. 
948

\section{References}

Aleksandrov B.A.,1971. Issledovanije vzaimidejstvija osnovanija mekhanizirovannoj krepi s pochvoj. Kamerovo, Trudy KUZPI nr 38, s. 24-29.

Fokin B.P., Gricajuk B.I., Zel'cev Ju.G., 1980. Sovershenstvovanie mekhanizirovannykh kriepiej dla raboty na slabykh pochvakh. Ugol, nr 9, s. 58-60.

Gricajuk B.I., 1979. O wzaimodejjstvii dvustoechnojj ograditel'no poddierzhivajushhejj mekhanizirovannoj krepi z pochvojj. Ugol, nr 1, s. 48-52.

Peng S.S., Chiang H.S.,1984. Longwall Mining John Wiley and sons. New York, Brisbane, Toronto Singapore.

Wala T., 1976. Statika Stitovych vyztuzi. Spravodaj BVU nr 1, s. 8-10.

GEOSOFT, 2013. Geomechanics and Control of Soft Mine Floors and Sides - Report of the project realized within Research Fund for Coal and Steel (RFCR-CT-2010-00001), realized in the years $2010 \div 2013$. 